\title{
Prioritizing landscapes for grassland bird conservation with hierarchical community models
}

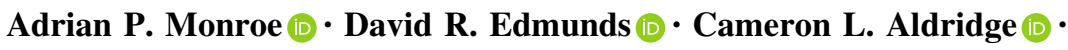 \\ Matthew J. Holloran • Timothy J. Assal (iD) Alison G. Holloran
}

Received: 25 June 2020/Accepted: 8 February 2021/Published online: 6 March 2021

(C) This is a U.S. government work and not under copyright protection in the U.S.; foreign copyright protection may apply 2021

\begin{abstract}
Context Given widespread population declines of birds breeding in North American grasslands, management that sustains wildlife while supporting rancher livelihoods is needed. However, management effects vary across landscapes, and identifying areas with the greatest potential bird response to conservation is a pressing research need.

Objectives We developed a hierarchical modeling approach to study grassland bird response to habitat factors at multiple scales and levels. We then identified areas to prioritize for implementing a birdfriendly ranching program.
\end{abstract}

Supplementary Information The online version contains supplementary material available at (https://doi.org/10.1007/ s10980-021-01211-z).

A. P. Monroe $(\varangle) \cdot$ D. R. Edmunds

Natural Resource Ecology Laboratory, Colorado State University, in Cooperation with the U.S. Geological

Survey, Fort Collins Science Center, Fort Collins, CO, USA

e-mail: amonroe@usgs.gov

Present Address:

A. P. Monroe · D. R. Edmunds

U.S. Geological Survey, Fort Collins Science Center,

Fort Collins, CO, USA

C. L. Aldridge

U.S. Geological Survey, Fort Collins Science Center,

Fort Collins, CO, USA
Methods Using bird survey data from grassland passerine species and 175 sites (2009-2018) across northeast Wyoming, USA, we fit hierarchical community distance sampling models and evaluated drivers of site-level density and regional-level distribution. We then created spatially-explicit predictions of bird density and distribution for the study area and predicted outcomes from pasture-scale management scenarios.

Results Cumulative overlap of species distributions revealed areas with greater potential community response to management. Within each species' potential regional-level distribution, the grassland bird community generally responded negatively to cropland cover and vegetation productivity at local scales (up to $10 \mathrm{~km}$ of survey sites). Multiple species

M. J. Holloran

Operational Conservation LLC, Fort Collins,

$\mathrm{CO}, \mathrm{USA}$

T. J. Assal

Department of Geography, Kent State University, Kent, $\mathrm{OH}$, USA

A. G. Holloran

Audubon Rockies, Fort Collins, CO, USA 
declined with increasing bare ground and litter cover, shrub cover, and grass height measured within sites. Conclusions We demonstrated a novel approach to multi-scale and multi-level prioritization for grassland bird conservation based on hierarchical community models and extensive population monitoring. Pasturescale management scenarios also suggested the examined community may benefit from less bare ground cover and shorter grass height. Our approach could be extended to other bird guilds in this region and beyond.

Keywords Biodiversity · Hierarchy · Ranching · Scale $\cdot$ Working lands

\section{Introduction}

Habitat loss and degradation have contributed to widespread population declines among many avian species (Gaston et al. 2003; Rosenberg et al. 2019). Management for habitats and restoration of ecological processes are needed to avert additional losses, but actions must be matched with the appropriate biological scale (Jackson and Fahrig 2015). Indeed, conservation efforts may be more successful if multi-scale heterogeneity in resource conditions and habitat configuration are considered (Boyd et al. 2008), which affect movement and persistence of individuals (Fahrig 2013; Riffell et al. 2015; Saunders et al. 2019). Furthermore, it is often useful to understand processes occurring within spatial hierarchies, where lower levels form components of higher levels and higher levels place constraints and context for processes below (Johnson 1980; Wu 2013). A species, for example, may be dramatically influenced by environmental attributes at fine scales within its distribution (Urban et al. 1987; O'Neill et al. 1989) but respond little to management occurring beyond its geographic range (Scott et al. 2001).

Globally, the grassland biome has experienced some of the highest rates of conversion (Hoekstra et al. 2005), and bird populations breeding in North American grasslands declined by nearly two thirds over the last half-century (Rosenberg et al. 2019). Many of these declines are attributed to habitat loss from cultivation, woody encroachment, and exotic grass invasion (Brennan and Kuvlesky 2005; Stanton et al.
2018). Among remaining grasslands, management paradigms reduced biodiversity by eliminating habitat for species favoring different levels of vegetation structure (Fuhlendorf and Engle 2001; Derner et al. 2009; Toombs and Roberts 2009). Managing rangelands with biodiversity-friendly practices could promote habitat for the full complement of grassland bird species, but effectiveness likely varies with landscape structure (composition and distribution of patches; Pillsbury et al. 2011; Duchardt et al. 2016) and the scale of practices relative to population processes and habitat. For example, modifying vegetation height within a pasture may create optimal structure and microhabitat for Grasshopper Sparrows (Ammodramus savannarum; e.g., Davis et al. 2020), but have limited impacts if the broader landscape is unsuitable (Wiens 1989; Levin 1992; Bakker et al. 2003). This complexity is compounded when one considers multiple community members with different habitat requirements. Given finite resources available for conservation, identifying where best to apply these practices within and among landscapes is a pressing research need.

This challenge is illustrated by conservation efforts underway among grasslands of northeast Wyoming, USA. Through the Conservation Ranching Initiative, Audubon Rockies works with ranchers to implement sustainable practices that also benefit birds. Implementation costs may discourage producers from incorporating bird-friendly management in their operations (Monroe et al. 2017b; Raynor et al. 2019), and therefore economic incentives are important (Drum et al. 2015). Unlike commodity-based or cost-share programs, the Conservation Ranching Initiative is market-based, where conservation actions are marketed directly to consumers. In exchange for developing a Habitat Management Plan that can include resting pastures and completing livestock maturation on pasture, the land is certified by National Audubon Society as "bird friendly", and beef produced from these rangelands can be sold at a premium or in an alternative market space. As this program expands, targeted enrollment is needed toward grasslands with the greatest potential to support abundant and diverse bird populations. Specifically, efficient implementation of this program requires an approach that (1) systematically examines habitat associations at multiple scales and hierarchical levels, (2) identifies habitat requirements of multiple species, and (3) 
integrates this information to predict conservation outcomes from management on working lands.

We therefore demonstrate an approach to identifying priority areas for grassland bird conservation in the Powder River-Thunder Basin region of northeast Wyoming using hierarchical community models. We studied bird densities among 175 survey sites in response to ground-based (within $50 \mathrm{~m}$ ) and localscale (up to $10 \mathrm{~km}$ ) habitat measurements while considering potential species distributions across the broader study region $\left(>64,000 \mathrm{~km}^{2}\right)$. We also used relationships with ground-based habitat measurements to infer potential management objectives for each species and predict community responses. Hierarchical community models assume species-level parameters are drawn from community-level hyperparameters, and this information sharing permits analyzing counts from species with sparse records and estimating community-level statistics, such as richness, within a unified framework (Sollmann et al. 2016). Because responses to site-level factors were both constrained by, and components of, regionallevel bird distributions, our approach extended hierarchical community models to consider a spatial hierarchy of species density and distribution across the study landscape.

\section{Methods}

Study area

We conducted this study in northeast Wyoming within the Badlands and Prairies Bird Conservation Region (BCR 17, Fig. 1). The study area $\left(64,464 \mathrm{~km}^{2}\right)$ is comprised of high plains and is part of the unglaciated Missouri Plateau sub-region of the Great Plains province. The area is characterized by open high hills and sagebrush-grassland tablelands with intermittent escarpments. Elevation ranges from 947 to $2242 \mathrm{~m}$, and climate is typical of a semi-arid, high plains steppe environment with large variations in seasonal temperatures and recurring periods of extended drought. Mean annual minimum and maximum temperatures (1981-2010) were $-0.1{ }^{\circ} \mathrm{C}$ and $15.2{ }^{\circ} \mathrm{C}$, respectively (NOAA 2020), and mean annual precipitation was $38 \mathrm{~cm}$ (NOAA 2020). The study area proper is comprised of a mix of sagebrush steppe and mixedgrass prairie with some encroaching stands of conifers.
Wyoming big sagebrush (Artemisia tridentata wyomingensis) dominates sagebrush steppe while silver sagebrush (A. cana) and black greasewood (Sarcobatus vermiculatus) occur in drainage bottoms. Jurisdiction is primarily private $(77 \%)$, followed by federal (15\%) and state (8\%; BLM 2020). Most (87\%) of the land is in use as rangeland, whereas $3 \%$ is used for crop production (TBGPEA 2020). Energy production (coal and gas/oil) is widespread in the region, and there is high potential for additional habitat loss from energy development and cultivation (Walker et al. 2007).

\section{Bird surveys}

Over 10 years (2009-2018), trained field technicians conducted all bird counts following protocols from the Integrated Monitoring in Bird Conservation Regions (IMBCR) monitoring program (McLaren et al. 2019). Technicians conducted counts at sites each consisting of up to 16 points arranged in a $4 \times 4$ grid, with points spaced $250 \mathrm{~m}$ apart. Ninety sites were located across the study area based on Generalized Random Tessellation Stratification (GRTS; Stevens and Olsen 2004), a balanced sampling algorithm (Pavlacky et al. 2017), and 35 sites were established for monitoring on federal lands (Fig. 1). Beginning in 2016, an additional 50 sites were distributed among ranches enrolled in the Conservation Ranching Initiative. Number of points surveyed at each site varied among years from 1 to 16 (median =12), and each site was surveyed for $1-10$ years (median $=7$ years), totaling 617 siteyears (hereafter, surveys). Technicians conducted counts once during the breeding season (May 13-July 20) from approximately $0.5 \mathrm{~h}$ before sunrise until $5 \mathrm{~h}$ after sunrise. During each point count, one observer recorded the minute when an individual or cluster of birds was first detected (out of $5 \mathrm{~min}$ in 2009, 6 min thereafter), species observed, and unlimited radial distance $(m)$ from the observer.

\section{Local-scale habitat}

We compiled data characterizing local landscapes around the centroid of each site, including vegetation productivity, agricultural cover, and well density. Vegetation productivity, approximated by the Normalized Difference Vegetation Index (NDVI), can indicate local-scale habitat conditions for grassland 


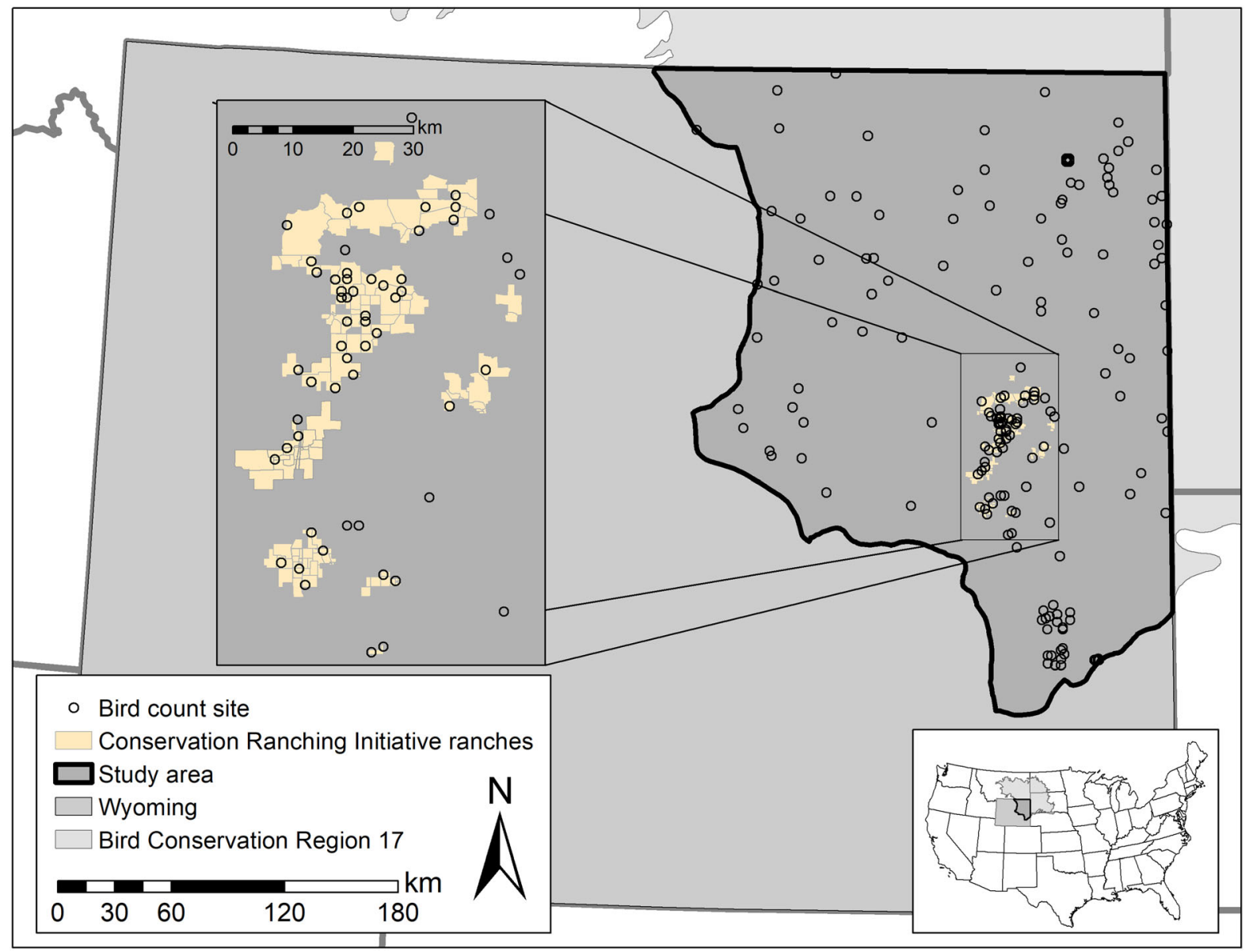

Fig. 1 Location of bird count sites $(n=175)$ relative to Conservation Ranching Initiative ranches across the study area encompassed by Bird Conservation Region 17 (Badlands and Prairies) within Wyoming, USA

birds (Green et al. 2018), cropland cover may negatively affect grassland bird distribution (Guttery et al. 2017), and both positive and negative associations have been observed with density of energy development (Kalyn Bogard and Davis 2014; Ludlow et al. 2015). We acquired NDVI data from Moderate Resolution Imaging Spectroradiometer (MODIS; Huete et al. 2002) 16-day composites (250 m resolution, MOD13Q1) during January-October, 2009-2018. We used the maximum value for each pixel across composites each year as an index of annual vegetation productivity (Monroe et al. 2017a). We estimated cropland cover with the "plowprint" dataset (Gage et al. 2016), which indicates annually whether cropland occurs within each 30-m pixel, including agricultural commodities planted annually and fallowed agricultural land. Although NDVI may reveal similar aspects of agricultural cover (such as amount of vegetation biomass; Gu et al. 2013), we used plowprint to distinguish between cropland and rangeland vegetation. We identified the number of active oil and gas wells across the study landscape using location and activity data from the Wyoming Oil and Gas Commission (accessed 8 July 2019). Like plowprint, changes in vegetation from energy development can be captured with NDVI (Allred et al. 2015), so we used well density (see below) as an index of anthropogenic features associated with oil and gas wells. For consistency, we resampled NDVI and well data to the same resolution $(30 \mathrm{~m})$ and projection as plowprint. 
Ground-based habitat measurements

After completing each point count, technicians visually estimated vegetation conditions within $50 \mathrm{~m}$ of the point count location (McLaren et al. 2020), including percent cover of bare ground and litter, percent shrub cover, and estimated height $(\mathrm{cm})$ of combined live grass, residual grass, and other herbaceous plants (hereafter, grass height). Grass height and bare ground cover are useful predictors of grassland bird habitat (Fisher and Davis 2010), and bare ground is a common indicator related to the integrity and function of rangeland ecosystems (Pyke et al. 2002; Pellant et al. 2005; Veblen et al. 2014). Shrub cover was relevant because our study area lies at the edge of the sagebrush biome and shrubs may affect grassland bird distribution (Davis 2005). There were slight changes in vegetation survey protocols over the course of the study period (e.g., bare ground and litter cover were estimated separately in 2018; McLaren et al. 2020), so for consistency we made several modifications to point-level vegetation data before analysis (detailed in Appendix S1).

\section{Statistical analyses}

We restricted our analyses to 15 passerine species that breed in grasslands and were detected during surveys (Table 1; Rosenberg et al. 2019). We analyzed point count data using a hierarchical community model with distance sampling (Sollmann et al. 2016) that also estimated availability for detection (Nichols et al. 2009; Amundson et al. 2014). This model consisted of a process model representing the true (but latent, or unobserved) abundance and distribution of birds and a data model for the observation process. We assumed species-level responses were drawn from common distributions described by community-level hyperparameters. For example, effect of plowprint cover on species $i\left(\beta_{1, i}\right)$ was sampled from a normal distribution with hyperparameters for the mean $\left(\mu_{\beta 1}\right)$ and variance $\left(\sigma_{\beta 1}^{2}\right): \beta_{1, i} \sim \mathrm{N}\left(\mu_{\beta 1}, \sigma_{\beta 1}^{2}\right)$. We therefore posited a mean community response while accommodating variation among community members. We analyzed data at the site level, summing counts and averaging ground-based covariates among points at each survey, and including an offset in the process model for number of points in each survey.

\section{Process model}

Because the study area encompassed distributions of multiple species with varying degrees of overlap, we used a zero-inflated Poisson model to distinguish between processes determining potential regionallevel distributions (suitability), and processes for sitelevel abundance, given a site was suitable. We began by modeling suitability of site during survey $j(\operatorname{site}(j))$ for each species $i$ with a Bernoulli distribution and probability $\psi_{i, \operatorname{site}(j)}$ :

$z_{i, j} \sim \operatorname{Bernoulli}\left(\psi_{i, \text { site }(j)}\right)$

We used a two-dimensional thin plate spline to allow for non-linear effects of latitude and longitude on $\psi_{i, \text { site }(j)}$ (Wood 2017; Rushing et al. 2019), thereby modeling suitability as a function of location within the broader study region. This approach involved specifying a smooth function $(f)$ defined by the basis function $g_{k}$ with $K-1$ dimensions and parameters $\alpha_{k, i}$ where the degree of smoothing was determined by a penalty term ( $\lambda$; Wood 2016):

$f\left(\operatorname{lat}_{i, \operatorname{site}(j)}, \operatorname{lon}_{i, \operatorname{sit}(j)}\right)=\sum_{k=1}^{K-1} g_{k}\left(\operatorname{lat}_{\operatorname{site}(j)}, \operatorname{lon}_{\operatorname{sit}(j)}\right) \alpha_{k, i}$

$\operatorname{logit}\left(\psi_{i, \operatorname{site}(j)}\right)=\alpha_{0, i}+f\left(\operatorname{lat}_{i, \operatorname{site}(j)}, \operatorname{lon}_{i, \operatorname{site}(j)}\right)$

Given that a site was suitable for species $i\left(z_{i, j}=1\right)$, site-level abundance $\left(N_{i, j}\right)$ was the outcome of a Poisson distribution with mean $\mu_{i, j}$ :

$N_{i, j} \mid z_{i, j} \sim \operatorname{Poisson}\left(\mu_{i, j} \times z_{i, j}\right)$

We fit multiple coefficients $(\beta)$ to $\mu_{i, j}$ on the logscale for site-level covariates, a random term for survey and species $\left(\varepsilon_{i, j}\right)$, and an offset for the natural $\log$ of number of points surveyed:

$$
\begin{aligned}
& \log \left(\mu_{i, j}\right)= \beta_{0, i}+\beta_{1, i} \text { grshght }_{j}+\beta_{2, i} \text { ground }_{j} \\
&+\beta_{3, i} \text { hrub }_{j}+\beta_{4, i} \text { wells }_{j}+\beta_{5, i} \text { plowprint }_{j} \\
&+\beta_{6, i} \text { NDVI }_{j}+\beta_{7, i} \text { NDVI }_{j}^{2}+\text { offset }_{j}+\varepsilon_{i, j} \\
& \varepsilon_{i, j} \sim \mathrm{N}\left(0, \sigma_{\text {surv }}^{2}\right)
\end{aligned}
$$

For surveys where ground-based habitat data were not collected, we imputed missing data assuming 
Table 1 Common names, species names, and number of detections for grassland passerine species detected among 175 survey sites in northeast Wyoming (2009 - 2018). We also report Partners in Flight (PIF) regional combined scores for the breeding season, which indicate the conservation priority of each species based on factors related to extinction vulnerability (Panjabi et al. 2019)

\begin{tabular}{lllll}
\hline Common name & Species name & Species code & Detections & PIF \\
\hline Baird's Sparrow & Centronyx bairdii & BAIS & 1 & 16 \\
Cassin's Sparrow & Peucaea cassinii & CASP & 6 & 11 \\
Chestnut-collared Longspur & Calcarius ornatus & CCLO & 51 & 19 \\
Clay-colored Sparrow & Spizella pallida & CCSP & 32 & 9 \\
Eastern Kingbird & Tyrannus tyrannus & EAKI & 385 & 12 \\
Grasshopper Sparrow & Ammodramus savannarum & GRSP & 2084 & 16 \\
Horned Lark & Eremophila alpestris & HOLA & 4873 & 13 \\
Lark Bunting & Calamospiza melanocorys & LARB & 11,531 & 17 \\
Lark Sparrow & Chondestes grammacus & LASP & 1917 & 12 \\
Loggerhead Shrike & Lanius ludovicianus & LOSH & 291 & 14 \\
Savannah Sparrow & Passerculus sandwichensis & SAVS & 44 & 8 \\
Thick-billed Longspur & Rhynchophanes mccownii & TBLO & 81 & 17 \\
Vesper Sparrow & Pooecetes gramineus & VESP & 3216 & 15 \\
Western Kingbird & Tyrannus verticalis & WEKI & 692 & 9 \\
Western Meadowlark & Sturnella neglecta & WEME & 23,596 & 12 \\
\hline
\end{tabular}

population-level hyperparameters of each covariate (Royle 2009).

We used a scale selection method to identify relevant spatial scales for each local covariate (Frishkoff et al. 2019). We created matrices $\left(E_{j, s}\right)$ for mean NDVI, proportion of plowprint cover, and well density $\left(\mathrm{km}^{-2}\right)$ within buffers $(s)$ with increasing radii (100 m to $10 \mathrm{~km}$, in $100-\mathrm{m}$ increments) from the site centroid during survey $j$. Although sites were in Wyoming, some site buffers extended beyond state boundaries. Because we lacked well data beyond Wyoming, we assumed buffer parts within Wyoming represented well density of the entire buffer. We used $10 \mathrm{~km}$ as an upper limit for grassland birds (e.g., Thogmartin et al. 2006) to reduce the chance of missing relationships at larger scales (Jackson and Fahrig 2015). The model then estimated the most likely scale based on a uniform distribution for scale parameter $\varsigma$ and linear interpolation between adjacent buffers (Frishkoff et al. 2019). For example, well density at $500 \mathrm{~m}(\varsigma=5)$ yielded: wells $\mathrm{s}_{j}=E_{j, 5}$. We assumed species in this grassland bird community responded similarly to local-scale covariates, so for each covariate we assigned all species the same scale parameter. We summarized posterior distributions of scale parameters with $95 \%$ credible intervals (CrI) and interpreted the mode as the best scale for predictions.

\section{Data model}

In this system, we assumed the observation process was governed by availability probability (i.e., visible and/or singing when present) and detection probability (the process of perceiving an individual, given they are present and available; Nichols et al. 2009). Like the process model, species-level parameters were drawn from community-level hyperparameters. We estimated availability probability for each species and survey $\left(p_{a_{i, j}}\right)$ using a time-removal model with a conditional multinomial formulation (Amundson et al. 2014). We estimated multinomial cell probabilities $\left(\pi_{a_{i, j, t}}\right)$ from availability probability in each of $T$ time intervals $\left(a_{i, j}\right): \pi_{a_{i, j, t}}=a_{i, j}\left(1-a_{i, j}\right)^{t-1}$. Summing cell probabilities across time intervals yielded an overall availability probability for each survey: $p_{a_{i, j}}=\sum_{t=1}^{T} \pi_{a_{i, j, t}}$. We fit linear and quadratic effects of ordinal date and a random term for year $\left(\eta_{\text {year }(j)}\right)$ to $a_{i, j}$ on the logit scale to account for within-season variation in availability:

$\operatorname{logit}\left(a_{i, j}\right)=\delta_{0, i}+\delta_{1, i}$ date $_{j}+\delta_{2, i}$ date $_{j}^{2}+\eta_{\text {year }(j)}$

Time intervals of each detection $c$ (tinterval ${ }_{c, i}$ ) were then sampled from a categorical distribution with conditional cell probability $\pi_{a_{i, j, t}}^{c}$, where $\pi_{a_{i, j, t}}^{c}=\frac{\pi_{a_{i, j, t}}}{p_{a_{i, j}}}$ and tinterval $\mathrm{l}_{c, i} \sim \operatorname{Categorical}\left(\pi_{a_{i, j, 1: T}}^{c}\right)$. 
We similarly used the conditional multinomial formulation for distance sampling to estimate probability of detecting a species in each survey $\left(p_{d_{i, j}}\right.$; Amundson et al. 2014). We first right-truncated the farthest $\sim 10 \%$ of detection distances (Buckland et al. 2001, p. 151), and we assigned detection distances to 5 distance classes (b), each $50 \mathrm{~m}$ in length (v), with midpoint radial distance $r_{b}$ (in hectometers). We then calculated multinomial cell probabilities $\left(\pi_{d_{b, i, j}}\right)$ for detection probability in each distance class, where each cell probability is approximated by the product of a probability density function $\left(f(r)_{b, i, j}\right)$ representing the radial distance of the distance class relative to the maximum detection distance $\left(\max _{\mathrm{d}}\right)$ :

$f(r)_{b, i, j}=\frac{2 r_{b} v}{\max _{\mathrm{d}}^{2}}$

and a half-normal distance function $\left(g(r)_{b, i, j}\right)$ :

$g(r)_{b, i, j}=\exp \left(-\frac{r_{b}^{2}}{2 \sigma_{i, j}^{2}}\right)$

$\pi_{d_{b, i, j}} \approx f(r)_{b, i, j} g(r)_{b, i, j}$

Shape of the detection function was determined by a scale parameter $(\sigma)$, to which we fit a random term for observer $\left(\omega_{\mathrm{obs}(j)}\right)$ and a coefficient $(\gamma)$ for observer experience $\left(\mathrm{OE}_{j}\right)$ where $\mathrm{OE}_{j}=0$ during the first year a technician conducted surveys and $\mathrm{OE}_{j}=1$ for subsequent years:

$\log \left(\sigma_{i, j}\right)=\gamma_{0, i}+\gamma_{1, i} \mathrm{OE}_{j}+\omega_{\mathrm{obs}(j)}$

We summed multinomial cell probabilities to estimate an overall detection probability for each species and survey: $p_{d_{i, j}}=\sum_{b=1}^{B} \pi_{d_{b, i, j}}$. We assumed a categorical distribution for detection distances $\left(\right.$ dclass $_{c, i}$ ) given conditional multinomial cell probability $\quad \pi_{d_{b, i, j}}^{c}, \quad$ where $\quad \pi_{d_{b, i, j}}^{c}=\frac{\pi_{d_{b, i, j}}}{p_{d_{i, j}}} \quad$ and $\operatorname{dclass}_{c, i} \sim$ Categorical $\left(\pi_{d_{1: B, i, j}}^{c}\right)$.

Individuals detected in clusters were not independent, so we based inferences on the number of clusters (hereafter, abundance) rather than individuals (Buckland et al. 2001). Nevertheless, relatively few detections $(4.9 \%)$ consisted of $>1$ individual. Total count of each species by survey $\left(y_{i, j}\right)$ was drawn from a binomial distribution given survey-level abundance, availability probability, and detection probability:

$y_{i, j} \mid N_{i, j} \sim \operatorname{Binomial}\left(N_{i, j}, p_{a_{i, j}} \times p_{d_{i, j}}\right)$

We fit this model in a Bayesian framework using NIMBLE (v. 0.91; de Valpine et al. 2016) in R ( $R$ Development Core Team 2020). We specified vague priors for parameters including $\mu_{\beta} \sim \mathrm{N}(0,9)$, $\mu_{\delta} \sim \mathrm{N}(0,9), \quad \mu_{\gamma} \sim \mathrm{N}(0,9), \quad \sigma_{\text {surv }} \sim \operatorname{Unif}(0,3)$, $\sigma_{\text {year }} \sim \operatorname{Unif}(0,3), \sigma_{\text {obs }} \sim \operatorname{Unif}(0,3)$, $\alpha_{0, i} \sim \mathrm{N}(0,2.72)$, and $\log (\lambda) \sim \operatorname{Unif}(-12,12)$. For hyperparameter variance terms, we used weaklyinformative half-Cauchy priors (Gelman et al. 2008; Broms et al. 2016) with scale parameters $\sigma=10$ for intercepts and $\sigma=2.5$ for coefficients. We used this type of prior to accommodate sparse data from certain species in hierarchical community models (Broms et al. 2016). Model code is reported in Appendix S2. Prior to analysis, we standardized each continuous covariate by subtracting the sample mean and dividing by the sample standard deviation. We then generated $1,000,000$ samples each from three parallel chains, discarding the first 50,000 and saving every 200th sample from each chain, yielding 14,250 posterior samples for inference. We assessed parameter convergence by visually examining chains and with the Gelman-Rubin statistic ( $\hat{R}$; Gelman et al. 2014), where model parameters indicated convergence was achieved with $\hat{R}<1.1$. We evaluated model fit using posterior predictive checks (Bayesian $P$-values) comparing chi-squared discrepancy statistics for observed and predicted counts summed across surveys (Amundson et al. 2014). Finally, we interpreted $95 \%$ credible intervals that did not overlap 0 as indicating strong support for covariate effects.

To identify the appropriate number of basis dimensions $(K)$ for the thin plate spline, we fit models with either $K=20,30,40$, or 50, and compared model performance with a posterior predictive loss criterion (Gelfand and Ghosh 1998; Hooten and Hobbs 2015). This model selection approach involves calculating a predictive loss term representing the level of predictive error, and a penalty term that increases when models are overparameterized. Models with smaller posterior loss criteria are therefore favored because they denote smaller predictive errors with fewer parameters. We used the squared error between predicted $\left(\tilde{y}_{i, j}\right)$ and observed counts $\left(y_{i, j}\right)$ and for 
predictive loss, and variance in predicted counts for the penalty (Dorazio and Connor 2014). Summing the predictive loss and penalty across species and surveys produced the following statistic $(D)$ :

$D=\sum_{i} \sum_{j}\left(\mathrm{E}\left(\tilde{y}_{i, j} \mid d a t a\right)-y_{i, j}\right)^{2}+\sum_{i} \sum_{j} \operatorname{Var}\left(\tilde{y}_{i, j} \mid d a t a\right)$

We used parameter estimates from the best-supported model to make two sets of predictions: one set for density and distribution across the study area based on local-scale covariates and the suitability model, and another set using ground-based measurements within a ranch to infer potential responses to management. We estimated densities (bird ha ${ }^{-1}$ ) from the maximum detection distance used in our model $\left(\frac{\mu_{i} \times z_{i}}{\pi \times \max _{d}^{2}}\right)$, and predictions were based on 2018 maps of local-scale variables (plowprint, well density, and NDVI). Because we lacked ground-based habitat measurements for pixels across the study area, we used sample mean values of these covariates for predictions. We therefore used all available information to make predictions across the landscape while acknowledging that predictions may improve with additional data from ground-based measurements. To avoid extrapolating predictions beyond conditions observed near our sample sites, we masked areas with local-scale variables beyond $95 \%$ of any covariate sample. We also combined predictions into community-level measures weighted by the conservation value of each species. Such weightings may better describe a location's conservation priority than abundance or diversity by incorporating additional information such as extinction risk (Götmark et al. 1986; Nuttle et al. 2003). For weights, we used Partners in Flight regional scores for BCR 17 during the breeding season $\left(\mathrm{PIF}_{i}\right)$, which combined several scores for conservation vulnerability based on population size and trend, geographic extent of their breeding range, and threats to reproduction (Panjabi et al. 2019). Higher scores indicate species with greater conservation priority, and we summed weighted potential distribution and density predictions across species to obtain conservation values in potential richness $\left(\mathrm{CV}_{S}\right)$ and total density $\left(\mathrm{CV}_{N}\right)$, respectively:
$\mathrm{CV}_{S}=\sum_{i=1}^{15} \mathrm{z}_{i} \times \mathrm{PIF}_{i}$

$\mathrm{CV}_{N}=\sum_{i=1}^{15}\left(\frac{\mu_{i} \times z_{i}}{\pi \times \max _{d}^{2}}\right) \times \mathrm{PIF}_{i}$

To evaluate sensitivity of bird community predictions to changes in ground-based habitat measurements, and therefore illustrate potential effects of management, we predicted $\mathrm{CV}_{N}$ across pastures in one ranch enrolled in the Conservation Ranching Initiative (Fig. 1) but with $25 \%$ decreases in bare ground and litter cover, shrub cover, or grass height because of their purported relationships with grassland bird concealment and nest success (Davis 2005; Fisher and Davis 2010). We created baseline predictions after interpolating ground-based habitat measurements from $n=29$ sites in 2018 distributed among ranches enrolled in the Conservation Ranching Initiative (Appendix S3), and then compared percent changes in $\mathrm{CV}_{N}$ from decreases in each ground-based habitat component relative to baseline predictions.

\section{Results}

Model selection based on posterior predictive loss $(D)$ indicated that 40 basis dimensions were better supported for the regional-level spatial term (thin plate spline; $D=153,731)$ than other dimensions considered (20 knots: 153,894; 30 knots: 153,786; 50 knots: $153,820)$. Posterior predictive checks did not indicate lack of fit for this model (Bayesian $P$-value 0.30-0.67 across species). Regional-level trends indicated species varied from nearly ubiquitous (Western Meadowlark [Sturnella neglecta]) to rare (e.g., Cassin's Sparrow [Peucaea cassinii]; Appendix S4, Fig. S1). Credible intervals of mean hyperparameters for several site-level parameters overlapped 0 (Appendix S4, Table S1). Exceptions were negative effects of NDVI at the local scale and bare ground and litter cover and shrub cover from ground-based measurements.

At the site level, scale selection parameters indicated a mode at $3.2 \mathrm{~km}$ for vegetation productivity (NDVI; 95\% CrI 2.3-4.5 km), whereas well density effects occurred at broader scales (mode $=9.6 \mathrm{~km}$, 95\% CrI 5.6-10.0 km; Appendix S4, Fig. S2). We estimated two modes for plowprint cover, with the 
highest density occurring at $6.8 \mathrm{~km}$ and another mode near the upper limit (95\% CrI 6.1-9.9 km). We used $6.8 \mathrm{~km}$ to predict plowprint effects while acknowledging effects at broader scales were possible. Among sites occurring within each species' regional-level distribution, we estimated higher densities of 4 species (Chestnut-collared Longspur [Calcarius ornatus], Grasshopper Sparrow, Lark Sparrow [Chondestes grammacus], Thick-billed Longspur [Rhynchophanes mccownii]) and fewer Western Meadowlark with increasing well density (Fig. 2a, Appendix S4 Fig. S3). Densities of four species (Grasshopper Sparrow, Lark Bunting [Calamospiza melanocorys], Lark Sparrow, Western Meadowlark) declined with greater plowprint cover whereas Western Kingbird (Tyrannus verticalis) increased (Fig. 2a, Appendix S4 Fig. S4). As NDVI increased, Horned Lark (Eremophila alpestris), Western Kingbird, and Western Meadowlark densities declined, Vesper Sparrow (Pooecetes gramineus) increased, and densities of Grasshopper Sparrow and Lark Bunting were highest at intermediate levels (Appendix S4 Fig. S5).

Among ground-based habitat attributes measured at sites within each species' potential regional-level distribution, three species (Horned Lark, Vesper Sparrow, and Western Meadowlark) declined with increasing grass height whereas most species indicated neutral responses (Fig. 2b, Appendix S4 Fig. S6). Twelve species declined with increasing bare ground and litter cover (Fig. 2b, Appendix S4 Fig. S7), and we estimated negative responses to shrub cover by five species (Eastern Kingbird [Tyrannus tyrannus], Grasshopper Sparrow, Horned Lark, Lark Sparrow, and Western Kingbird; Appendix S4 Fig. S8).

Using predictions of potential species distribution (Appendix S4 Fig. S1) and density (Appendix S4 Fig. S9) from across the study area, we estimated conservation values in potential richness $\left(\mathrm{CV}_{S}\right)$ and density $\left(\mathrm{CV}_{N}\right)$ were highest around the center of the study area and lowest in the northeast (Fig. 3). When altering habitat across pastures in one ranch (Fig. 4a), reducing grass height by $25 \%$ produced modest increases in $\mathrm{CV}_{N}$ (4-10\% change; Fig. 4b). Decreasing bare ground and litter cover had a greater effect among eastern pastures of the ranch (up to $17 \%$ change; Fig. 4c), where baseline $\mathrm{CV}_{N}$ was low (Fig. 4a) and bare ground and litter cover was high (Appendix S3, Fig. S3). Effects of shrub cover reduction were more equivocal for this community ( -1 to $5 \%$ change; Fig. $4 \mathrm{~d}$ ).

Availability for detection was generally constant across the survey period for most species (Fig. 2c, Appendix S4 Fig. S10), but availability was highest mid-season for Grasshopper Sparrow and later in the season for Horned Lark and Loggerhead Shrike (Lanius ludovicianus). Observers with $>1$ year of experience were more likely to detect individuals from three species (Lark Bunting, Vesper Sparrow, Western Meadowlark) at greater distances than first-year observers whereas first-year observers detected Grasshopper Sparrow and Horned Lark slightly farther than more experienced observers (Fig. 2d, Appendix S4 Fig. S11).

\section{Discussion}

Prioritizing areas for conservation is often more effective than random or opportunistic strategies (Scott et al. 2001; Bonnot et al. 2013) and understanding habitat relationships at multiple scales and hierarchical levels can inform such prioritizations. Here, we found hierarchical community models were useful in predicting potential habitat for grassland passerines breeding in northeast Wyoming, and applicable to prioritizing enrollment in the Conservation Ranching Initiative. Importantly, our approach considers factors measured at multiple scales that may influence density of community members while accounting for observation error. Inherent in this framework are spatial hierarchies of species distribution (Wu 2013), where density at any given location is conditional on the location's status within the broader study region (potential distribution). We identified, for example, areas where potential distributions of conservation priority species often overlapped (high $\mathrm{CV}_{S}$; Fig. 3) and modifying habitat is more likely to increase the conservation value of grassland bird communities (greater $\mathrm{CV}_{N}$ ) than areas with low $\mathrm{CV}_{S}$. Within regional-level distributions, we also could determine potential constraints to management of sitelevel habitat from local-scale factors such as cropland cover and vegetation productivity. However, some community-level responses to pasture-scale management scenarios were relatively modest despite associations of individual species with ground-based habitat measurements (e.g., grass height). This latter result 
Fig. 2 Mean species-level parameter estimates (and $95 \%$ credible intervals) for local-scale habitat (up to $10 \mathrm{~km}$ from sites; a), ground-based habitat measurements (within $50 \mathrm{~m}$; b), availability for detection (c), and detection probability (d) from a hierarchical community distance sampling model for grassland passerine species in northeast Wyoming, USA. Species codes are arranged by color and defined in Table 1
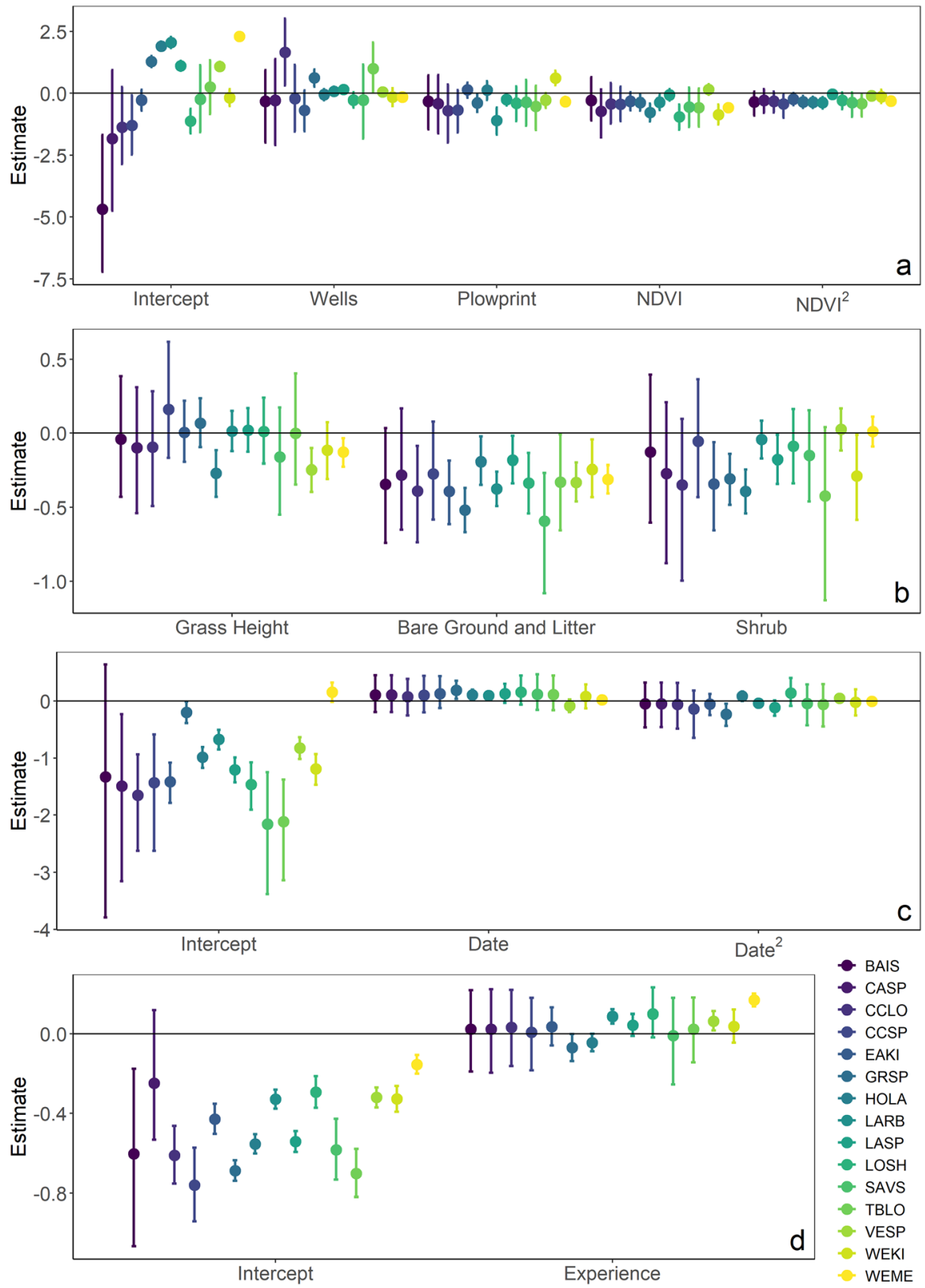

highlights a benefit of studying all community members jointly, rather than extrapolating a common response from individual umbrella or indicator species to the rest of the community (White et al. 2013; Loman et al. 2018).

At local scales, greater density of Horned Lark at lower NDVI levels agrees with their reported affinity for areas with short, sparse vegetation (Dinkins et al. 2019). Grasshopper Sparrow and Lark Bunting indicated clear peaks in density with NDVI levels resembling northern mixed grass prairie (Paruelo and Lauenroth 1995). This pattern also may reflect associations with intermediate levels of cover and structure (Duchardt et al. 2018). Several species were positively associated with well density, although we note well densities within $9.6 \mathrm{~km}$ of survey sites were lower than other parts of the landscape (maximum $=2.7$ wells $\mathrm{km}^{-2}$ vs. maximum $=5.9$ wells $\mathrm{km}^{-2}$, 


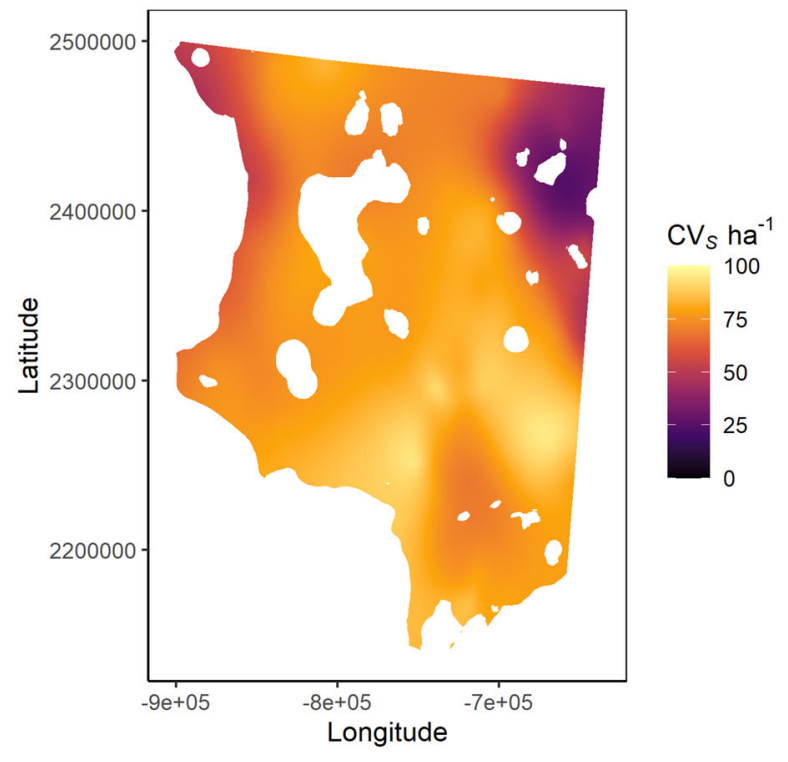

Fig. 3 Predicted conservation value in potential richness $\left(\mathrm{CV}_{S}\right.$; left) and total density $\left(\mathrm{CV}_{N}\right.$; right) derived from a hierarchical community distance sampling model for grassland passerine species in northeast Wyoming, USA. Pixels without color represent areas masked because local-scale factors were above

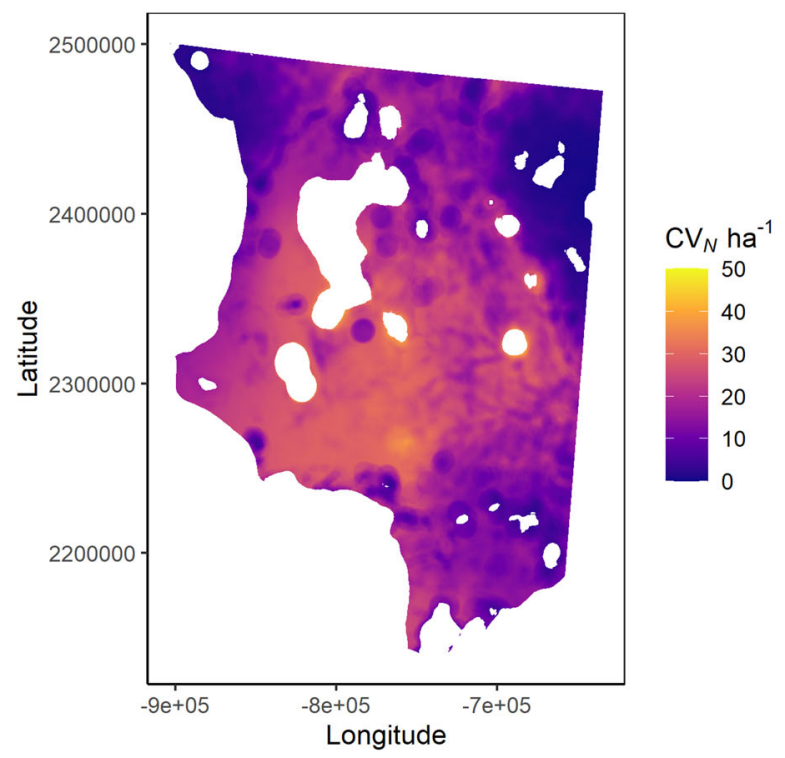

or below $95 \%$ of our covariate samples. Density and richness were weighted by conservation priority of each species as indicated by Partners in Flight (PIF) breeding season combined scores
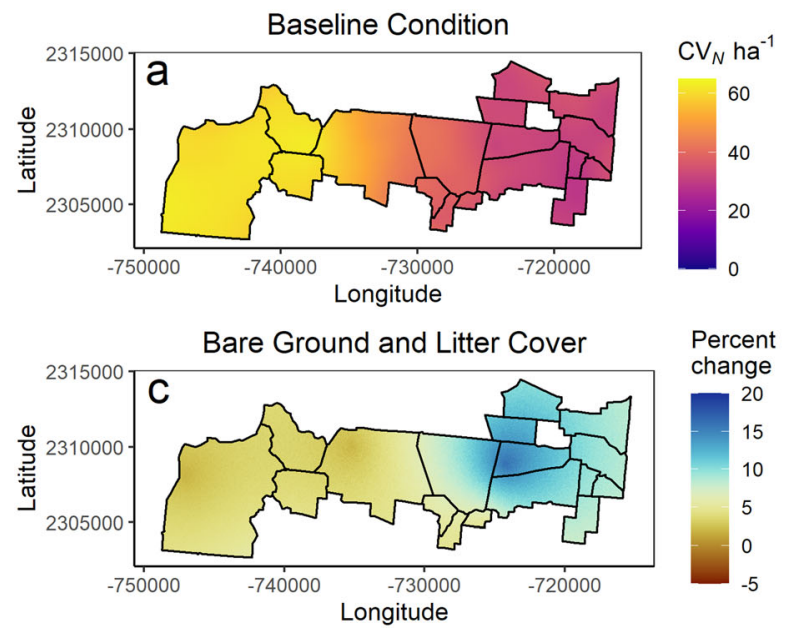

Fig. 4 Predicted percent change in baseline estimates of conservation value in total density of grassland birds, per ha (a) $\mathrm{CV}_{N} \mathrm{ha}^{-1}$, weighted by Partners in Flight [PIF] combined scores) after reducing grass height (b), bare ground and litter

respectively). Including NDVI in our models also likely accounted for vegetation altered or removed by energy development (Allred et al. 2015), and responses to infrastructure (e.g., roads, vertical structures) can vary among grassland bird species (Kalyn Bogard and Davis 2014; Ludlow et al. 2015).
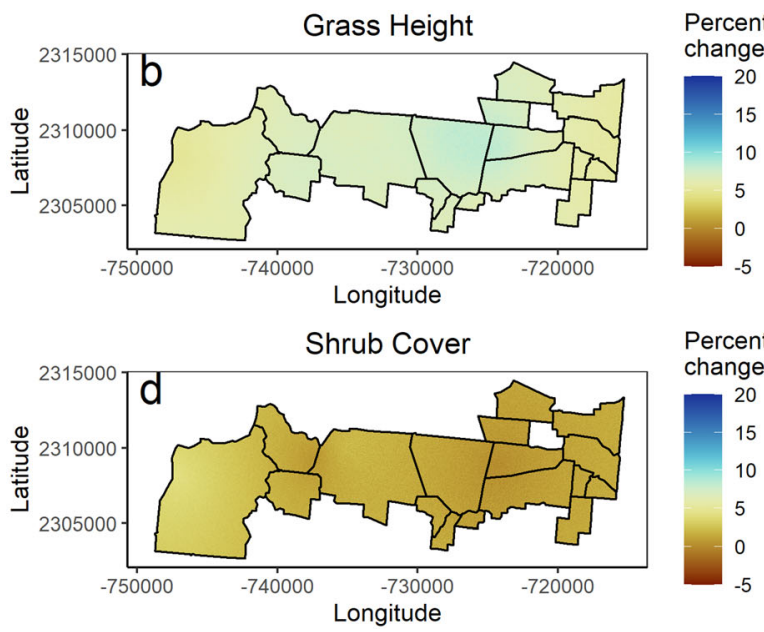

cover (c), or shrub cover (d) by $25 \%$, across pastures from one ranch in northeast Wyoming, USA (see Fig. 1 for geographic context)

Similarly, responses to plowprint cover likely reflected broader co-occurrence of species on the landscape with low levels of this land use (at $6.8 \mathrm{~km}$ scale, maximum $=0.07$ plowprint proportion vs. maximum $=0.40$ plowprint proportion across the study area), and these results do not preclude impacts 
of additional cropland conversion through loss of grassland habitat (Quinn et al. 2017; Herse et al. 2018). We refrained from extending our model predictions beyond the range of covariates in our sample given the relatively limited representation of well density and plowprint, and additional sampling and analyses in other areas could provide further insights into their effects on grassland passerine communities.

One of the top indicators used to assess rangeland conditions across the Western United States is bare ground cover (Veblen et al. 2014), which can increase with improper ungulate grazing (Veblen et al. 2014) and lead to degradation by wind and water erosion (Pyke et al. 2002; Pellant et al. 2005). We found the community responded most to reductions in bare ground and litter cover, and pasture-scale scenarios indicated greater increases in conservation value by prioritizing management of this cover type in eastern pastures of the ranch. Although birds may respond differently to bare ground and litter (Fisher and Davis 2010), technicians estimated bare ground and litter cover together during all years except 2018 (for consistency, we combined both measures that year for analysis; Appendix S1). Still, based on 2018 data, bare ground was greater on average (30.7\%) than litter cover $(25.3 \%)$ and bare ground was somewhat negatively correlated with litter cover $(r=-0.29)$. These patterns lend modest support to the hypothesis that bare ground cover was a stronger driver of observed relationships between species and this covariate. If reductions in bare ground cover are prescribed to improve rangeland health, our results suggest such actions also may benefit grassland passerine communities breeding in this landscape. We caution, however, when interpreting spatial trends in density as indicators of habitat quality, and additional demographic data are needed to test our assumptions (Van Horne 1983; Johnson 2007). We also note that uniform reductions in bare ground and shrub cover could negatively impact shrubland-breeding guilds that we did not consider here (Aldridge et al. 2011; Duchardt et al. 2018). More generally, our management scenarios should be interpreted as heuristic rather than viable options. Indeed, extrapolating habitat requirements across scales can be problematic (Smith et al. 2020), and a more plausible scenario may involve increasing heterogeneity in vegetation cover and structure at different scales to support the entire bird community breeding in this landscape (Knopf 1996; Derner et al. 2009; Davis et al. 2020).

Fewer species responded to variation in shrub cover and grass height than bare ground and litter cover. Negative responses to shrub cover conform with previous studies of Grasshopper Sparrow (Dechant et al. 2002) and Horned Lark (Dinkins et al. 2019). Still, many other species in this study exhibited neutral responses to shrub cover, and pasture-scale shrub management produced slight increases and decreases in $\mathrm{CV}_{N}$. Similarly, no species increased in density with greater grass height whereas three species declined (Appendix S4, Fig. S6), and we estimated more modest community responses to reductions in grass height than bare ground and litter cover. Still, few detections may have prevented adequately evaluating this relationship for short structure specialists like Thick-billed Longspur. Phenological changes in grass height during the breeding season also could obscure this relationship (Gibson et al. 2016; McConnell et al. 2017; Smith et al. 2018), and species may be responding to vegetation beyond the 50-m sampling radius.

In addition to benefits of studying community members jointly with hierarchical models, we note several implications of this approach. Credible intervals of several community-level means overlapped 0 , possibly reflecting variable responses among species despite being assigned to the same guild (Pacifici et al. 2014; Riffell et al. 2015). We could have further classified the study community into sub-groups (e.g., by microhabitat preference; Duchardt et al. 2019), but substantial differences in community-level metrics such as richness are unlikely (Pacifici et al. 2014). Additionally, although hierarchical community models allowed us to include several uncommon species, we could not adequately evaluate their responses to most covariates, and they contributed little to our community predictions. Also, it is unclear whether species with sparse records were breeding because our study area often occurred at the edge of their geographic ranges.

Study-wide predictions (maps; Fig. 3) revealed areas to the north and east of ranches currently enrolled in the Conservation Ranching Initiative with potentially high conservation values in richness $\left(\mathrm{CV}_{S}\right)$, and high conservation values in total density $\left(\mathrm{CV}_{N}\right)$ to the west, although trends in $\mathrm{CV}_{S}$ and $\mathrm{CV}_{N}$ tended to be similar overall. These predictions also 
indicated areas where enrolling ranches would have more limited potential to conserve habitat for grassland bird communities, such as among forested areas in the northeast of the study area. Collectively, insights derived from this analysis can help plan expansion of the Conservation Ranching Initiative, ensuring resources are invested in areas most likely to benefit bird communities requiring habitat improvements, given the context of landscape conditions and species distributions. Additionally, we prioritized areas for species vulnerable to population decline, restricted geographic extent, and other threats (Panjabi et al. 2019), but other priorities could be identified and weighted accordingly (e.g., Michel et al. 2020). With continued monitoring, our modeling approach could measure changes in population size following management actions, thereby indicating a direct link between conservation outcomes and the price paid by consumers in part for those outcomes. Quantifying these relationships also may support marketing efforts and outreach to recruit rancher participation. When paired with extensive and systematic monitoring, our framework can be extended beyond the study area and to other guilds that use rangelands, such as shrublandand wetland-breeding birds, further informing conservation programs for these communities.

Acknowledgements We thank J. Timmer, Bird Conservancy of the Rockies (BCR), and the Integrated Monitoring in Bird Conservation Regions (IMBCR) Partnership for sharing their bird count datasets, M. O'Donnell for acquiring oil and gas data from Wyoming Oil and Gas Commission, S. Olimb for sharing the plowprint dataset, and Audubon Rockies for supporting this work. We also are grateful to C. Amundson, A. Chalfoun, C. Duchardt, the Conservation Modeling Collective (J. Heinrichs), N. Van Lanen, and three anonymous reviewers for offering comments on earlier manuscript drafts. Any use of trade, firm, or product names is for descriptive purposes only and does not imply endorsement by the U.S. Government.

Open Access This article is licensed under a Creative Commons Attribution 4.0 International License, which permits use, sharing, adaptation, distribution and reproduction in any medium or format, as long as you give appropriate credit to the original author(s) and the source, provide a link to the Creative Commons licence, and indicate if changes were made. The images or other third party material in this article are included in the article's Creative Commons licence, unless indicated otherwise in a credit line to the material. If material is not included in the article's Creative Commons licence and your intended use is not permitted by statutory regulation or exceeds the permitted use, you will need to obtain permission directly from the copyright holder. To view a copy of this licence, visit http://creativecommons.org/licenses/by/4.0/.

Author contributions All authors contributed to study conception, design, and data collection. All analyses were conducted by APM. The first manuscript draft was written by APM, DRE, and MJH, and all authors commented on previous manuscript versions.

Data availability All IMBCR data are available from BCR on reasonable request. All other datasets were generated from publicly available sources but are available from the corresponding author on reasonable request.

\section{References}

Aldridge CL, Hanser SE, Nielsen SE, Leu M, Cade BS, Saher DJ, Knick ST (2011) Detectability adjusted count models of songbird abundance. In: Hanser SE, Leu M, Knick ST, Aldridge CL (eds) Sagebrush ecosystem conservation and management: ecoregional assessment tools and models for the Wyoming Basins. Allen Press, Lawrence, Kansas, pp 141-220

Allred BW, Smith WK, Twidwell D, Haggerty JH, Running SW, Naugel DE, Fuhlendorf SD (2015) Ecosystem services lost to oil and gas in North America: net primary production reduced in crop and rangelands. Science 348:401-402

Amundson CL, Royle JA, Handel CM (2014) A hierarchical model combining distance sampling and time removal to estimate detection probability during avian point counts. Auk 131:476-494

Bakker JD, Wilson SD, Christian JM, Li X, Ambrose LG, Waddington J (2003) Contingency of grassland restoration on year, site, and competition from introduced grasses. Ecol Appl 13:137-153

Bonnot TW, Thompson FR III, Millspaugh JJ, Jones-Farrand DT (2013) Landscape-based population viability models demonstrate importance of strategic conservation planning for birds. Biol Conserv 165:104-114

Boyd C, Brooks TM, Butchart SHM, Edgar GJ, da Fonseca GAB, Hawkins F, Hoffmann M, Sechrest W, Stuart SN, Paul van Dijk P (2008) Spatial scale and the conservation of threatened species. Conserv Lett 1:37-43

Brennan LA, Kuvlesky WP Jr (2005) North American grassland birds: an unfolding conservation crisis? J Wildl Manage 69:1-13

Broms KM, Hooten MB, Fitzpatrick RM (2016) Model selection and assessment for multi-species occupancy models. Ecology 97:1759-1770

Buckland ST, Anderson DR, Burnham KP, Laake JL, Borchers DL, Thomas L (2001) Introduction to distance sampling: estimating abundance of biological populations. Oxford University Press, Oxford

Bureau of Land Management [BLM] (2020) BLM national surface management agency area polygons: national geospatial data asset (NGDA). https://catalog.data.gov/ 
dataset/blm-national-surface-management-agency-areapolygons-national-geospatial-data-asset-ngda. Accessed 26 Oct 2020

Davis SK (2005) Nest-site selection patterns and the influence of vegetation on nest survival of mixed-grass prairie passerines. Condor 107:605-616

Davis KP, Augustine DJ, Monroe AP, Derner JD, Aldridge CL (2020) Adaptive rangeland management benefits grassland birds utilizing opposing vegetation structure in the shortgrass steppe. Ecol Appl 30:e02020

Dechant JA, Sondreal ML, Johnson DH, Igl LD, Goldade CM, Nenneman MP, Euliss BR (2002) Effects of management practices on grassland birds: Grasshopper Sparrow. USGS Northern Prairie Wildlife Research Center, Jamestown

Derner JD, Lauenroth WK, Stapp P, Augustine DJ (2009) Livestock as ecosystem engineers for grassland bird habitat in the Western Great Plains of North America. Rangel Ecol Manag 62:111-118

de Valpine P, Turek D, Paciorek CJ, Anderson-Bergman C, Temple Lang D, Bodik R (2016) Programming with models: writing statistical algorithms for general model structures with NIMBLE. J Comput Graph Stat 26:403-413

Dinkins MF, Igl LD, Shaffer JA, Johnson DH, Zimmerman AL, Parkin BD, Goldade CM, Euliss BR (2019) The effects of management practices on grassland Birds-Horned Lark (Eremophila alpestris). In: Johnson DH, Igl LD, Shaffer JA, DeLong JP (eds) The effects of management practices on grassland birds. U.S. Geological Survey Professional Paper 1842, p 24

Dorazio RM, Connor EF (2014) Estimating abundances of interacting species using morphological traits, foraging guilds, and habitat. PLoS ONE 9:e94323

Drum RG, Ribic CA, Koch K, Lonsdorf E, Grant E, Ahlering M, Barnhill L, Dailey T, Lor S, Mueller C, Pavlacky DC Jr, Rideout C, Sample D (2015) Strategic grassland bird conservation throughout the annual cycle: linking policy alternatives, landowner decisions, and biological population outcomes. PLoS ONE 10:e0142525

Duchardt CJ, Miller JR, Debinski DM, Engle DM (2016) Adapting the fire-grazing interaction to small pastures in a fragmented landscape for grassland bird conservation. Rangel Ecol Manag 69:300-309

Duchardt CJ, Porensky LM, Augustine DJ, Beck JL (2018) Disturbance shapes avian communities on a grasslandsagebrush ecotone. Ecosphere 9:e02483

Duchardt CJ, Augustine DJ, Beck JL (2019) Threshold responses of grassland and sagebrush birds to patterns of disturbance created by an ecosystem engineer. Landsc Ecol 34:895-909

Fahrig L (2013) Rethinking patch size and isolation effects: the habitat amount hypothesis. J Biogeogr 40:1649-1663

Fisher RJ, Davis SK (2010) From Wiens to Robel: a review of grassland-bird habitat selection. J Wildl Manag 74:265-273

Frishkoff LO, Mahler DL, Fortin M-J (2019) Integrating over uncertainty in spatial scale of response within multispecies occupancy models yields more accurate assessments of community composition. Ecography 42:2132-2143
Fuhlendorf SD, Engle DM (2001) Restoring heterogeneity on rangelands: ecosystem management based on evolutionary grazing patterns. Bioscience 51:625-632

Gage AM, Olimb SK, Nelson J (2016) Plowprint: Tracking cumulative cropland expansion to target grassland conservation. Gt Plains Res 26:107-116

Gaston KJ, Blackburn TM, Goldewijk KK (2003) Habitat conversion and global avian biodiversity loss. Proc R Soc B Biol Sci 270:1293-1300

Gelfand AE, Ghosh SK (1998) Model choice: a minimum posterior predictive loss approach. Biometrika 85:1-11

Gelman A, Jakulin A, Pittau MG, Su Y-S (2008) A weakly informative default prior distribution for logistic and other regression models. Ann Appl Stat 2:1360-1383

Gelman A, Carlin JB, Stern HS, Dunson DB, Vehtari A, Rubin DB (2014) Bayesian data analysis, 3rd edn. CRC Press, New York

Gibson D, Blomberg EJ, Sedinger JS (2016) Evaluating vegetation effects on animal demographics: the role of plant phenology and sampling bias. Ecol Evol 6:3621-3631

Götmark F, Ảhlund M, Eriksson MOG (1986) Are indices reliable for assessing conservation value of natural areas? An avian case study. Biol Conserv 38:55-73

Green AW, Pavlacky DC Jr, George TL (2018) A dynamic multi-scale occupancy model to estimate temporal dynamics and hierarchical habitat use for nomadic species. Ecol Evol 9:793-803

Gu Y, Wylie BK, Howard DM, Phuyal KP, Ji L (2013) NDVI saturation adjustment: a new approach for improving cropland performance estimates in the Greater Platte River Basin, USA. Ecol Indic 30:1-6

Guttery MR, Ribic CA, Sample DW, Paulios A, Trosen C, Dadisman J, Schneider D, Horton JA (2017) Scale-specific habitat relationships influence patch occupancy: defining neighborhoods to optimize the effectiveness of landscapescale grassland bird conservation. Land Ecol 32:515-529

Herse MR, With KA, Boyle WA (2018) The importance of core habitat for a threatened species in changing landscapes. J Appl Ecol 55:2241-2252

Hoekstra JM, Boucher TM, Ricketts TH, Roberts C (2005) Confronting a biome crisis: global disparities of habitat loss and protection. Ecol Lett 8:23-29

Hooten MB, Hobbs NT (2015) A guide to Bayesian model selection for ecologists. Ecol Monogr 85:3-28

Huete A, Didan K, Miura T, Rodriguez EP, Gao X, Ferreira LG (2002) Overview of the radiometric and biophysical performance of the MODIS vegetation indices. Remote Sens Environ 83:195-213

Jackson HB, Fahrig F (2015) Are ecologists conducting research at the optimal scale? Global Ecol Biogeogr 24:52-63

Johnson DH (1980) The comparison of usage and availability measurements for evaluating preference. Ecol 61:65-71

Johnson MD (2007) Measuring habitat quality: a review. Condor 109:489-504

Kalyn Bogard HJ, Davis SK (2014) Grassland songbirds exhibit variable responses to proximity and density of natural gas wells. J Wildl Manag 78:471-482

Knopf FL (1996) Prairie legacies_-birds. In: Samson FB, Knopf FL (eds) Prairie conservation. Island Press, Washington, DC, pp 135-148 
Levin SA (1992) The problem of pattern and scale in ecology. Ecology 73:1943-1967

Loman ZG, Monroe AP, Riffell SK, Miller DA, Vilella FJ, Wheat BR, Rush SA, Martin JA (2018) Nest survival modelling using a multi-species approach in forests managed for timber and biofuel feedstock. J Appl Ecol 55:937-946

Ludlow SM, Brigham RM, Davis SK (2015) Oil and natural gas development has mixed effects on the density and reproductive success of grassland songbirds. Condor Ornithol Appl 117:64-75

McConnell MD, Monroe AP, Burger LW, Martin JA (2017) Timing of nest vegetation measurement may obscure adaptive significance of nest-site characteristics: a simulation study. Ecol Evol 7:1259-1270

McLaren MF, White CM, Van Lanen NJ, Birek JJ, Berven JM, Hanni DJ (2019) Integrated Monitoring in Bird Conservation Regions (IMBCR): field protocol for spatially-balanced sampling of land bird populations. Bird Conservancy of the Rockies, Brighton, Colorado, USA

McLaren MF, Smith M, Timmer JM, Drilling NE, Green AW, Leslie BJ, White CM, Van Lanen NJ, Pavlacky DC Jr, Sparks RA, Van Boer AG (2020) Integrated Monitoring in Bird Conservation Regions (IMBCR): 2019 Field Season Report. Bird Conservancy of the Rockies, Brighton, Colorado, USA

Michel NL, Burkhalter C, Wilsey CB, Holloran M, Holloran A, Langham GM (2020) Metrics for conservation success: using the "Bird-Friendliness Index" to evaluate grassland and aridland bird community resilience across the Northern Great Plains ecosystem. Divers Distrib 26:1687-1702

Monroe AP, Aldridge CL, Assal TJ, Veblen KE, Pyke DA, Casazza ML (2017a) Patterns in Greater Sage-grouse population dynamics correspond with public grazing records at broad scales. Ecol Appl 27:1096-1107

Monroe AP, Burger LW Jr, Boland HT, Martin JA (2017b) Economic and conservation implications of converting exotic forages to native warm-season grass. Glob Ecol Conserv 11:23-32

National Oceanic and Atmospheric Administration [NOAA] (2020) National Centers for Environmental Information. http://www.ncdc.noaa.gov/cdo-web/datasets\#GHCND. Accessed 11 June 2020

Nichols JD, Thomas L, Conn PB (2009) Inferences about landbird abundance from count data: recent advances and future directions. In: Thomson DL, Cooch EG, Conroy MJ (eds) Modeling demographic processes in marked populations. Springer, New York, pp 201-235

Nuttle T, Leidolf A, Burger LW Jr (2003) Assessing conservation value of bird communities with Partners in Flightbased ranks. Auk 120:541-549

O’Neill RV, Johnson AR, King AW (1989) A hierarchical framework for the analysis of scale. Landsc Ecol 3:193-205

Pacifici K, Zipkin EF, Collazo JA, Irizarry JI, DeWan A (2014) Guidelines for a priori grouping of species in hierarchical community models. Ecol Evol 4:877-888

Panjabi AO, Easton WE, Blancher PJ, Shaw AE, Andres BA, Beardmore CJ, Camfield AF, Demarest DW, Dettmers R, Keller RH, Rosenberg KV, Will T (2019) Avian conservation assessment database handbook, Version 2019.
Partners in Flight Technical Series No. 8. http://pif. birdconservancy.org/acad_handbook.pdf. Accessed 19 May 2020

Paruelo JM, Lauenroth WK (1995) Regional patterns of Normalized Difference Vegetation Index in North American shrublands and grasslands. Ecology 76:1888-1898

Pavlacky DC Jr, Lukacs PM, Blakesley JA, Skorkowsky RC, Klute DS, Hahn BA, Dreitz VJ, George TL, Hanni DJ (2017) A statistically rigorous sampling design to integrate avian monitoring and management within Bird Conservation Regions. PLoS ONE 12:e0185924

Pellant M, Shaver P, Pyke DA, Herrick JE (2005) Interpreting indicatiors of rangeland health, version 4. Technical Reference 1734-6, U.S. Department of the Interior, Bureau of Land Management, National Science and Technology Center, Denver, Colorado

Pillsbury FC, Miller JR, Debinski DM, Engle DM (2011) Another tool in the toolbox? Using fire and grazing to promote bird diversity in highly fragmented landscapes. Ecosphere 2:1-14

Pyke DA, Herrick JE, Shaver P, Pellant M (2002) Rangeland health attributes and indicators for qualitative assessment. J Range Manag 55:584-597

Quinn JE, Awada T, Trindade F, Fulginiti L, Perrin R (2017) Combining habitat loss and agricultural intensification improves our understanding of drivers of change in avian abundance in a North American cropland anthrome. Ecol Evol 7:803-814

R Development Core Team (2020) R: a language and environment for statistical computing. R Foundation for Statistical Computing, Vienna, Austria (version 3.6.3)

Raynor EJ, Coon JJ, Swartz TM, Wright Morton L, Schacht WH, Miller JR (2019) Shifting cattle producer beliefs on stocking and invasive forage: implications for grassland conservation. Rangel Ecol Manag 72:888-898

Riffell SK, Monroe AP, Martin JA, Evans KO, Burger LW Jr, Smith MD (2015) Response of non-grassland avian guilds to adjacent herbaceous field buffers: testing the configuration of targeted conservation practices in agricultural landscapes. J Appl Ecol 52:300-309

Rosenberg KV, Dokter AM, Blancher PJ, Sauer JR, Smith AC, Smith PA, Stanton JC, Panjabi A, Helft L, Parr M, Marra PP (2019) Decline of the North American avifauna. Science 366:120-124

Royle JA (2009) Analysis of capture-recapture models with individual covariates using data augmentation. Biometrics 65:267-274

Rushing CS, Royle JA, Ziolkowski DJ, Pardieck KL (2019) Modeling spatially and temporally complex range dynamics when detection is imperfect. Sci Rep 9:12805

Saunders SP, Hall KAL, Hill N, Michel NL (2019) Multiscale effects of wetland availability and matrix composition on wetland breeding birds in Minnesota, USA. Condor Ornithol Appl 121:1-15

Scott TA, Wehtje W, Wehtje M (2001) The need for strategic planning in passive restoration of wildlife populations. Restor Ecol 9:262-271

Smith JT, Tack JD, Doherty KE, Allred BW, Maestas JD, Berkeley LI, Dettenmaier SJ, Messmer TA, Naugle DE (2018) Phenology largely explains taller grass at successful nests in greater sage-grouse. Ecol Evol 8:356-364 
Smith JT, Allred BW, Boyd CS, Carlson JC, Davies KW, Hagen CA, Naugel DE, Olsen AC, Tack JD (2020) Are sagegrouse fine-scale specialists or shrub-steppe generalists? J Wildl Manag 84:759-774

Sollmann R, Gardner B, Williams KA, Gilbert AT, Veit RR (2016) A hierarchical distance sampling model to estimate abundance and covariate associations of species and communities. Methods Ecol Evol 7:529-537

Stanton RL, Morrissey CA, Clark RG (2018) Analysis of trends and agricultural drivers of farmland bird declines in North America: a review. Agric Ecosyst Environ 254:244-254

Stevens DL Jr, Olsen AR (2004) Spatially balanced sampling of natural resources. J Am Stat Assoc 99:262-278

Thunder Basin Grasslands Prairie Ecosystem Association [TBGPEA] (2020) Our landscape. https://tbgpea.org/ conservation/our-landscape. Accessed 23 Jan 2020

Thogmartin WE, Knutson MG, Sauer JR (2006) Predicting regional abundance of rare grassland birds with a hierarchical spatial count model. Condor 108:25-46

Toombs TP, Roberts MG (2009) Are Natural Resources Conservation Service range management investments working at cross-purposes with wildlife habitat goals on western United States rangelands? Rangel Ecol Manag 62:351-355

Urban DL, O'Neill RV, Shugart HH Jr (1987) Landscape ecology: a hierarchical perspective can help scientists understand spatial patterns. Bioscience 37:119-127

Van Horne B (1983) Density as a misleading indicator of habitat quality. J Wildl Manag 47:893-901
Veblen KE, Pyke DA, Aldridge CL, Casazza ML, Assal TJ, Farinha MA (2014) Monitoring of livestock grazing effects on Bureau of Land Management land. Rangel Ecol Manag 67:68-77

Walker BL, Naugle DE, Doherty KE (2007) Greater sagegrouse population response to energy development and habitat loss. J Wildl Manag 71:2644-2654

White AM, Zipkin EF, Manley PN, Schlesinger MD (2013) Conservation of avian diversity in the Sierra Nevada: moving beyond a single-species management focus. PLoS ONE 8:e63088

Wiens JA (1989) Spatial scaling in ecology. Funct Ecol 3:385-397

Wood SN (2016) Just Another Gibbs Additive Modeller: interfacing JAGS and mgcv. J Stat Softw 75:1-14

Wood SN (2017) Generalized Additive Models: an introduction with R, 2nd edn. CRC Press, Boca Raton

Wu J (2013) Hierachy theory: an overview. In: Rozzi R, Pickett STA, Palmer C, Armesto JJ, Callicott JB (eds) Linking ecology and ethics for a changing world. Ecology and ethics, vol 1. Springer, Dordrecht, pp 281-301

Publisher's Note Springer Nature remains neutral with regard to jurisdictional claims in published maps and institutional affiliations. 